\title{
Recombinant activated factor VII for acute intracerebral hemorrhage
}

\section{Sudhir Kumar}

Acute stroke is the third leading cause of death worldwide, exceeded only by coronary artery disease and cancer. ${ }^{[1]}$ There are two major subtypes of strokeischemic and hemorrhagic with $20-30 \%$ of all strokes being hemorrhagic in nature. ${ }^{[2]}$ The incidence of ischemic strokes has steadily declined by virtue of rigorous risk factor modification, but the same has not been possible for hemorrhagic strokes. Moreover, ischemic strokes can now be effectively treated by thrombolysis with tissue plasminogen activator. On the other hand, the incidence of intracerebral hemorrhage (ICH) is expected to grow, given the aging of the population. The treatment of hemorrhagic strokes remains mainly conservative with a recent large multi-centric study failing to show any benefit from early surgery ${ }^{[2]}$ and the mortality at 30 days is seven times higher than ischemic strokes $(63 \%$ vs. 9\%). ${ }^{[3]}$ However, it is believed that strict control of hypertension may significantly decrease the incidence of nonlobar type of $\mathrm{ICH}^{\left[{ }^{[4]}\right.}$ The above factors clearly point towards the need for newer drugs or treatment modalities for patients with $\mathrm{ICH}$. Recombinant activated factor VII ( $\mathrm{FVVIIa),} \mathrm{as} \mathrm{shown} \mathrm{in} \mathrm{some} \mathrm{recent} \mathrm{trials,} \mathrm{appears} \mathrm{to} \mathrm{be}$ of promise in the management of $\mathrm{ICH}^{\left[{ }^{[5]}\right.}$

\section{Rationale for using rFVIla in ICH}

Historically, bleeding due to a hemorrhagic stroke was considered to be a monophasic event that stopped quickly as a result of clotting and tamponade by the surrounding brain tissue. However, computerized tomography-based studies have demonstrated that the initial

\section{From:}

Neurology Department, Apollo Hospitals, Jubilee Hills, Hyderabad - 500 033, India

Correspondence:

Consultant Neurologist, Neurology Department, Apollo Hospitals, Jubilee Hills, Hyderabad - 500 033, India. E-mail: drsudhirkumar@yahoo.com hematoma expands in up to $38 \%$ of patients who were initially scanned within 3 hours of the onset of stroke, and in $16 \%$ of those scanned between 3 and 6 hours, even in the absence of coagulopathy. ${ }^{[6]}$ Progressive bleeding of this type has been associated with contrast extravasation on CT angiography ${ }^{[7]}$ and poor outcome after early ( $<4$ hours) surgical clot evacuation. ${ }^{[8]}$ On the basis of these observations, it is plausible that ultra-early hemostatic therapy given in the emergency room setting might improve outcome after $\mathrm{ICH}$ by arresting ongoing bleeding and minimizing the increase in the volume of the hematoma. rFVIla is approved to treat bleeding in patients with hemophilia who have antibodies to factor VIII or IX, and it has been reported to reduce bleeding in patients without coagulopathy as well. ${ }^{[9]}$

The precise mechanism by which rFVIla arrests bleeding in patients with acute $\mathrm{ICH}$ is not fully understood. It promotes hemostasis by activating the extrinsic pathway of the coagulation cascade. After blood-vessel damage and local initiation of the coagulation cascade, the administration of rFVIla enhances thrombin generation on the surface of activated platelets, leading to accelerated formation of a fibrin clot. ${ }^{[10]}$ It seems most likely that the administration of rFVIla after ICH accelerates thrombosis within ruptured small penetrating arteries or arterioles. Although the half-life of rFVIla is only 2.6 hours, a sustained hemostatic effect may occur after a single dose because the clot that forms is denser than normal and more resistant to fibrinolysis. ${ }^{[11]}$

\section{Current evidence regarding the efficacy of rFVIla in ICH \\ rFVIla for spontaneous $\mathrm{ICH}$ in adults}

In a recent multi-centre, double-blind, placebo-control- 
led trial, 399 adult patients with CT-documented $\mathrm{ICH}$ were randomized to receive either placebo or rFVIla (at a dose of 40,80 or $160 \mu \mathrm{g}$ per kilogram body weight) as a single intravenous dose within four hours of onset of symptoms (within one hour of CT). ${ }^{[5]}$ There was a greater increase in hematoma volume in the placebo group than in the rFVIla groups. The mean increase was $29 \%$ in the placebo group, as compared with $16 \%, 14 \%$, and $11 \%$ in the groups given $40 \mu \mathrm{g}, 80 \mu \mathrm{g}$, and $160 \mu \mathrm{g}$ of rFVIla per kilogram, respectively. Growth of the hematoma was reduced by $3.3 \mathrm{ml}, 4.5 \mathrm{ml}$, and $5.8 \mathrm{ml}$ in the three treatment groups, as compared with that in the placebo group. Outcome at 90 days was worse in the placebo group. Sixty-nine percent of placebo-treated patients died or were severely disabled, as compared with $55 \%, 49 \%$, and $54 \%$ of the patients who were given 40,80 , and $160 \mu \mathrm{g}$ of $\mathrm{rFVIla}$, respectively. Mortality was $29 \%$ for patients who received placebo, as compared with $18 \%$ in the three rFVIla groups combined. This study, therefore, establishes the efficacy of $\mathrm{rFVIla}$ in $\mathrm{ICH}$, if administered within four hours of symptom onset.

\section{Role of rFVIla in patients with ICH on warfarin thromboprophylaxis}

Major bleeding is a frequent and hazardous complication associated with thromboprophylaxis using vitamin$\mathrm{K}$ antagonists (VKA) such as warfarin. Suggested regimens for control of the elevated International Normalized Ratio (INR) and hemorrhagic events during VKA treatment include administration of vitamin $\mathrm{K}$, infusion of fresh frozen plasma or a prothrombin complex concentrate. However, correction of INR by these measures may take 24-48 hours; and for the patients who require an emergent neurosurgical intervention and evacuation of hematoma, early normalization of INR would be a distinct advantage. In a study on seven patients with oral-anticoagulant induced ICH (INR ranging from 1.7 to 6.6 ) requiring emergency neurosurgical intervention, rFVIla was administered at a dose of 10-40 $\mu \mathrm{g} / \mathrm{kg}$ body weight, ${ }^{[12]}$ which resulted in a reduction in the INR to 1.5 or less within 10 minutes of administration of rFVIla. Six patients underwent drainage of the hematoma and survived to hospital discharge.

\section{rFVIla therapy for ICH in patients with hemophilia A or $B$ with inhibitors}

The efficacy of rFVIla for ICH in hemophilia A patients with inhibitors was demonstrated more than a decade ago in a study on five patients. ${ }^{[13]}$ More recently, in a study on 12 patients with hemophilia and life-threatening $\mathrm{ICH}$ previously unresponsive to one or more alternate therapies; rFVIla was administered in an emergency setting, ${ }^{[14]}$ resulting in effective $\mathrm{ICH}$ control in 10 patients.

\section{rFVIla therapy in thrombocytopenic patients with ICH}

Efficacy of rFVIla in thrombocytopenic patients with $\mathrm{ICH}$ has been demonstrated with a few case reports. ${ }^{[15,16]}$ The clinical settings included patients with refractory thrombocytopenia or idiopathic thrombocytopenic purpura, who required emergency surgery and therapies with platelet rich concentrates or intravenous immunoglobulins had failed.

\section{rFVIla for cerebral-injury induced coagulopathy}

Coagulopathy is common in patients with moderate or severe head injury. In a recent study, thrombocytopenia and coagulopathy were present in $14 \%$ and $21 \%$ of patients at admission, which increased to $46 \%$ and $41 \%$ by the third day. ${ }^{[17]}$ Many patients with head injury require emergency neurosurgical intervention including evacuation of intracerebral hematoma and placement of intracranial pressure monitoring devices. The procedures may get delayed in presence of coagulopathy. In this setting, therapy with rFVIla could be useful. In a study on three pediatric patients, rFVIla at a dose of $90 \mu \mathrm{g} / \mathrm{kg}$ body weight was found to be effective in correcting the coagulopathy and allowing the neurosurgical procedures without any complication. ${ }^{[18]}$

\section{Adverse events with rFVIla therapy}

The major limitation with rFVIla therapy is its potential to cause thromboembolic complications. In a recent trial in patients with $\mathrm{ICH}$, serious thromboembolic adverse events occurred in $7 \%$ of rFVIla-treated group as compared to $2 \%$ in the placebo-treated group. ${ }^{[5]}$ Though the difference was statistically insignificant, it remains a cause for concern. The arterial thromboembolic events included myocardial or cerebral infarction and the majority occurred within three days of administration of rFVIla. There is a report of subdural vein thrombosis developing three weeks after rFVIla therapy for postnatal ICH in an infant. ${ }^{[19]}$ These reports suggest a need for careful monitoring of patients receiving rFVIla therapy.

\section{Dose, availability and cost}

rFVIla is manufactured and marketed by Novo Nordisk, Denmark as NovoSeven. It is supplied as a white, lyophilized powder in single use vials. It is available in two strengths- $1.2 \mathrm{mg}$ and $2.4 \mathrm{mg} .{ }^{[20]}$ Prior to reconstitution; 
it should be kept refrigerated $\left(2-8^{\circ} \mathrm{C}\right)$. It needs to be reconstituted with sterile water for injection prior to use. The recommended dose is $40-80 \mu \mathrm{g} / \mathrm{kg}$ body weight and is administered by the intravenous route as a bolus dose. NovoSeven is available in India too, costing approximately Rs. 35,000 and Rs. 75,000 for $1.2 \mathrm{mg}$ and 2.4 $\mathrm{mg}$ vials, respectively.

\section{Summary}

Recombinant activated factor VII therapy is effective and safe in patients with $\mathrm{ICH}$ and seems to be useful in a variety of clinical scenarios. These include spontaneous $\mathrm{ICH}$, warfarin-induced $\mathrm{ICH}$, bleeding associated with thrombocytopenia and coagulopathy occurring in head injury. The only point of concern seems to be its propensity to cause serious thromboembolic adverse events. Further trials are, however, needed to better determine its efficacy and safety.

\section{References}

1. Venketasubramanian N. The epidemiology of stroke in ASEAN countries- A review. Neurol J Southeast Asia 1998;3:9-14.

2. Mendelow AD, Gregson BA, Fernandes HM, Murray GD, Teasdale GM, Hope DT, et al. Early surgery versus initial conservative treatment in patients with spontaneous supratentorial intracerebral haematomas in the International Surgical Trial in Intracerebral Haemorrhage (STICH): A randomised trial. Lancet 2005;365:387-97.

3. Kiyohara Y, Kubo M, Kato I, Tanizaki Y, Tanaka K, Okubo K, et al. Ten-year prognosis of stroke and risk factors for death in a Japanese community: the Hisayama study. Stroke. 2003;34: 2343-7.

4. Woo D, Sauerbeck LR, Kissela BM, Khoury JC, Szaflarski JP, Gebel J, et al. Genetic and environmental risk factors for intracerebral hemorrhage: Preliminary results of a population-based study. Stroke 2002;33:1190-5.

5. Mayer SA, Brun NC, Begtrup K, Broderick J, Davis S, Diringer $\mathrm{MN}$, et al. Recombinant activated factor VII for acute intracerebral hemorrhage. N Engl J Med 2005;352:777-85.

6. Brott T, Broderick J, Kothari R, Barsan W, Tomsick T, Sauerbeck L, et al. Early hemorrhage growth in patients with intracerebral hemorrhage. Stroke 1997;28:1-5.

7. Becker KJ, Baxter AB, Bybee HM, Tirschwell DL, Abouelsaad T, Cohen WA. Extravasation of radiographic contrast is an independent predictor of death in primary intracerebral hemorrhage. Stroke 1999;30:2025-32.

8. Morgenstern LB, Demchuk AM, Kim DH, Frankowski RF, Grotta JC. Rebleeding leads to poor outcome in ultra-early craniotomy for intracerebral hemorrhage. Neurology 2001;56:1294-9.

9. Friederich PW, Henny CP, Messelink EJ, Geerdink MG, Keller $\mathrm{T}$, Kurth $\mathrm{KH}$, et al. Effect of recombinant activated factor VII on perioperative blood loss in patients undergoing retropubic prostatectomy: A double-blind placebo-controlled randomised trial. Lancet 2003;361:201-5.

10. Lindley CM, Sawyer WT, Macik BG, Lusher J, Harrison JF, BairdCox K, et al. Pharmacokinetics and pharmacodynamics of recombinant factor VIla. Clin Pharmacol Ther 1994;55:638-48.

11. He S, Blomback M, Ekman GJ, Hedner U. The role of recombinant factor VIla (FVIla) in fibrin structure in the absence of FVIII/FIX. J Thromb Haemost 2003;1:1215-9.

12. Sorensen B, Johansen $\mathrm{P}$, Nielsen GL, Sorensen JC, Ingerslev J. Reversal of the International Normalized Ratio with recombinant activated factor VII in central nervous system bleeding during warfarin thromboprophylaxis: Clinical and biochemical aspects. Blood Coagul Fibrinolysis 2003;14:469-77.

13. Schmidt ML, Gamerman S, Smith HE, Scott JP, DiMichele DM Recombinant activated factor VII (rFVIla) therapy for intracranial hemorrhage in hemophilia. A patients with inhibitors. Am J Hematol 1994;47:36-40.

14. Arkin S, Cooper HA, Hutter JJ, Miller S, Schmidt ML, Seibel NL, et al. Activated recombinant human coagulation factor VII therapy for intracranial hemorrhage in patients with hemophilia $A$ or $B$ with inhibitors. Results of the novoseven emergency-use program. Haemostasis 1998;28:93-8.

15. Vidarsson B, Onundarson PT. Recombinant factor VIla for bleeding in refractory thrombocytopenia. Thromb Haemost 2000;83: 634-5.

16. No authors listed. Use of recombinant activated factor VII (NovoSeven) in treatment of patients with idiopathic thrombocytopenic purpura complicated with subarachnoid and parenchimatous hemorrhage. Lik Sprava 2004;7:77-81.

17. Carrick MM, Tyroch AH, Youens CA, Handley T. Subsequent development of thrombocytopenia and coagulopathy in moderate and severe head injury: Support for serial laboratory examination. J Trauma 2005;58:725-30.

18. Morenski JD, Tobias JD, Jimenez DF. Recombinant activated factor VII for cerebral injury-induced coagulopathy in pediatric patients. Report of three cases and review of the literature. $J$ Neurosurg 2003;98:611-6.

19. Worth LL, Hoots WK. Development of a subdural vein thrombosis following aggressive factor VII replacement for postnatal intracranial haemorrhage in a homozygous factor VII-deficient infant. Haemophilia 1998;4:757-61.

20. NovoSeven prescribing information. http:// www.us.novoseven.com/content/us_vers/us_prescribing_ information.asp (accessed on March 17, 2005) 